\title{
How the Use of ICT can Contribute to a Misleading Picture of Conditions - A Five-Step Process
}

\author{
Stefan Holgersson \\ Department of Management and Engineering, \\ Division of Information Systems, \\ Linköping University, Linköping, Sweden
}

\author{
stefan.holgersson@liu.se
}

\begin{abstract}
This paper contributes to the limited research on roles ICT can play in impression-management strategies and is based on case studies done in the Swedish Police. It also gives a theoretical contribution by adopting a holistic approach to explain how ICT can contribute to giving a misleading picture of conditions. Output generated by ICT has nowadays a central role in follow-up activities and decision-making. Even if this type of output, often in colourful, presentable, graphical arrangements, gives the impression of being accurate and reliable there is a risk of defective data quality. The phenomena can be described as a process divided into five steps. The first step is about how the data is generated and/or collected. The second step is linked to how the data is registered. The third step is about the output generated from the ICT-systems. The fourth step is how the output of ICT is selected for presentation. The fifth step concerns how output generated by ICT is interpreted. This paper shows that ICT can easily be used in impression-management strategies. For example, that personnel take shortcuts to affect the statistics rather than applying methods that may give the desired effects.
\end{abstract}

Keywords: ICT, information quality, output, impression-management, misleading, decisionmaking

\section{Introduction}

Ackoff (1967) highlighted in his classic article titled "Management Misinformation Systems" that the main problem for managers was not a lack of relevant information, but an abundance of irrelevant information. This problem has not decreased with the introduction of Information Communication Technology (ICT), which makes it easy to generate outputs and to compile and compare the results of different organisations. A focus on key-figures, often generated by ICT, can easily lead to dysfunctional behaviour. This wide-ranging problem has been described by researchers

Material published as part of this publication, either on-line or in print, is copyrighted by the Informing Science Institute. Permission to make digital or paper copy of part or all of these works for personal or classroom use is granted without fee provided that the copies are not made or distributed for profit or commercial advantage AND that copies 1) bear this notice in full and 2) give the full citation on the first page. It is permissible to abstract these works so long as credit is given. To copy in all other cases or to republish or to post on a server or to redistribute to lists requires specific permission and payment of a fee. Contact Publisher@InformingScience.org to request redistribution permission. criticising the use of New Public Management, which has resulted in many negative effects for both organisations and society (see for example. Bejerot \& Hasselbladh, 2011; Lapsley, 2009; Speklé \& Verbeeten, 2014).

Alvesson (2013) describes that nowadays there is a strong desire for organisations, groups, and individuals to look good, where the focus is in surface ra- 
ther than the underlying quality. The use of ICT is one important part of this highly topical matter. Quantifying the reality and trusting in numbers has become very common, and information in databases is likely to be seen as a mapping of an "objective reality". That is because it is easy to use ICT to generate output that gives a good impression and looks accurate and reliable - but there are, however, reported risks that the output can give a misleading picture of conditions (Alvesson, 2013; Eterno \& Silverman, 2012).

In the context of the above, a valid question would be what previous research has been done to explain how the use of ICT can contribute to giving a misleading picture of conditions? By studying an extensive number of research articles which address the importance of appropriate systems design in avoiding errors when registering information with ICT, it is possible to find some explanations (see for example Ash, Berg, \& Coiera, 2004; Kushniruk, Triola, Borycki, Stein, \& Kannry, 2005). A system with an interface that heightens the risk that users make mistakes or that users are unmotivated to register some information will, of course, have a negative impact on the information quality. However, it is not just because of the design of an ICT system that information generated by ICT can be misleading. Knowledge can be divided into tacit and explicit knowledge (Polanyi, 1962), and tacit knowledge is difficult to register using ICT (Hislop, 2002). There also exists a social-technical gap between what we know we must support socially and what we can support technically (Ackerman, 2000). Furthermore, the use of ICT can be a part of impression-management strategies designed to create legitimacy. Legitimacy-building is a wellknown phenomenon and over the years many researchers have highlighted this situation (see e.g., DiMaggio, 1983; Meyer \& Rowan, 1977), but there is however limited research into what kind of different roles ICT can play in such strategies. Limited research has been done in cases where intentional misleading is caused by impression-management strategies; there are also hard-to-find studies that take a holistic approach to how the use of ICT can contribute to misleading pictures of conditions. To study cases where these conditions is manifested can, therefore, have theoretical implications by addressing a research gap, but also practical implications because ICT plays an increasing role in organisations and the whole society.

To be able to answer a research question about how the use of ICT can contribute to giving a misleading picture of conditions requires intimate access to an operation. It must be possible to follow the information process from the source - where data is generated and registered - to the end of the chain, i.e., how output from ICT is interpreted and its effects. The aim of the study is to adopt a holistic approach and to try to consider both intentional and unintentional causes in order to answer the research question. The study is limited to one organisation, the Swedish Police, where extensive field studies have been conducted ( $>10,000$ hours). The police have a central role in the public sector, where factors such as credibility and trust are important. The consequences of a misleading picture of conditions in such an organisation are, therefore, especially interesting to discuss. The paper begins with a section where previous research connected to the research question is presented, followed by a method section. Thereafter, there is an exemplification of circumstances that can explain what role ICT can play in giving a misleading picture of conditions, followed by an analysis. The paper concludes with a summary and a discussion section.

\section{Previous Research - The Role of ICT in Misleading Information}

In this section the aim is to present answers to the research question of how the use of ICT can contribute to a misleading picture of conditions using previous research. Even though it was not possible to find research with a holistic approach, trying to answer the question of how the use of ICT can contribute to giving a misleading picture of conditions; it was possible to find a wide range of single explanations that can be used to understand the phenomenon. For example, the 
extensive research field of Human-Computer Interaction (HCI) provides a number of explanations connected to the design of systems. Perceived usefulness and perceived ease-of-use are fundamental determinants of user acceptance, but usefulness had a significantly greater correlation with usage behaviour than how easy a system is to use (Davis, 1989). How well an IT system suits different user groups varies and the amount of effort required to learn and use an IT system may also vary (Grudin, 1988). Computer program design is essential to the actual use of computers in the workplace (see for example, Davis, Bagozzi, \& Warshaw, 2006) and will affect how information is registered and used. The use of ICT can cause errors (see Ash et al. 2004; Kushniruk et al; 2005). Ash et al. (2004) found that implementing patient care information systems seems to foster errors rather than reduce them. They describe that the errors fall into two main categories. The first is connected to the process of entering and retrieving information. The other is in the communication and coordination process. They pointed at the fact that physicians and nurses - just like people in general - tend to rely on information from computers being objective, and this can have damaging effect if the information gives a misleading picture of a patient's condition. They refer to a classic example (see Leveson \& Turner, 1993) with a computercontrolled radiation machine. The operators put so much faith in the information from the machine that everything was normal that they disregarded disturbing clinical signs from the patients. This caused radiation overdose in six patients. Ash et al. (2004) believe that it is possible that informaticians can design and implement systems, educate, and conduct research in such a way that it might be possible to avoid the unintended consequence of the type of silent errors they describe in their article. DeLone and McLean's (1992) widely referenced model in the information systems (IS) research area emphasised the importance of taking information quality into consideration when measuring the success or effectiveness of information systems. The risk of lack of information quality when using ICT, connected to how the system is designed, is thus a well-known factor and there are researchers that have pointed out that it is important to take system design into account when using data from IT systems (Nicolau \& McKnigth, 2011). The BI (Business Intelligence) research field emphasises the importance of using accurate information to be able to make appropriate operational judgements (see for example Ashrafi, Kelleher \& Kuilboer, 2014; Popovič \& Habjan, 2012). This indicates that there is an insight that an unreflective use of output generated by ICT can contribute to misleading pictures of conditions.

Besides the research areas mentioned above, there are also other types of research that might create an understanding of how ICT can contribute to giving a misleading picture of conditions. One factor is the identification of a social-technical gap, meaning that ICT cannot fully support the social world (Ackerman, 2000). Human activity is highly flexible, nuanced and contextualised, and knowledge includes both tacit and explicit elements (e.g., Nonaka, 1994). Knowledge recorded in an IT system is however "exposed knowledge" and "facts" (see, for example Hassel, 2005; Walsham, 2004). Hislop (2002) questions the perspective that ICT plays a central role in knowledge sharing processes, as it is difficult to share tacit knowledge through ICT and because all knowledge includes both tacit and explicit elements. Furthermore, different types of previous knowledge can negatively influence knowledge transfer, especially when some parts of the information are lacking. When one person's knowledge differs from another person's knowledge, the contents of the same information can be interpreted differently by two individuals (see for example, Lin, Geng, \& Whinston, 2005). Also social influence and different perspectives can affect the prerequisites for interpreting information about the organisation, its goals, and problems (see for example, Bolman \& Deal, 2003). That ICT nowadays plays a key role within organisations in persuasion, information exchange, and documentation (see for example, Novac-Ududec, 2015; Stephens, Sørnes, Rice, Browning, \& Sætre, 2008), together with the probability that some information is missing when using ICT - as is touched on in the research references above - give some explanation as to how the use of ICT might contribute to giving a misleading picture of conditions. So far, though, the references have only been used in a way that can explain uninten- 
tional misleading - such things as mistakes when registering information; important tacit information being difficult to catch; and the absence of important awareness of a context, which could cause inadequate interpreting of information generated by ICT. There is also the possibility that ICT might be used as a tool for legitimacy-building. It is important to consider whether any previous research can explain this matter.

Modern organisations, especially the public sector, have to respond to a high level of often contradictory demands, and it is an important strategy to promote a good image of the activities that they are involved in (Alvesson, 2013; see also Brunsson, 2003). There is a lot of research indicating that it is common for organisations to use different types of legitimacy-building activities (see for example, Alvesson, 2013; DiMaggio, 1983; Meyer \& Rowan, 1977), but research into the different roles ICT can play in such strategies is limited. There are, though, studies in the use of social media like Facebook, Twitter, or websites (see for example, Jackson \& Lilleker, 2011; Shin, Augustine, \& Hyo Jung, 2015). Even if they do not focus on how ICT can be used with the intention of giving a misleading picture of conditions, they describe how ICT can be an important part in impression-management strategies. If some facts are suppressed and other information is highlighted then this can, of course, create a too-positive image of a condition. There are also other types of IS research studies that describe how ICT can be a part of legitimacy-building activities. Melin, Sarkar, and Young (2014) show that cost savings and performance improvements are not the only motivators behind adoption of new ICT solutions in organisations. The decision to use new technologies can promote an innovative image of an organisation to stakeholders (Melin et al., 2014). In general, IS research that describes intentional misleading using ICT is hard to find. However there are studies in other research areas that substantially highlight impression-management strategies where ICT plays a key role.

Several researchers have found that focusing on quantitative information generated by ICT can cause different problems, such as dysfunctional behaviours (Bejerot \& Hasselblad, 2011; Eterno \& Silverman, 2012; Lapsley, 2009; Speklé \& Verbeeten, 2014) or manipulations (Eterno \& Silverman, 2012; Young, 1991). Eterno and Silverman (2012) identify how the New York Police put effort into giving the impression that the organisation operates in a certain way, even though it does not. An ICT system, called CompStat, has a central role in determining how successful units in the New York Police Department are in reducing crime. It is therefore important for managers that the system shows "good" figures and this pressure results in dysfunctional behaviours and manipulations. One example of dysfunctional behaviour is that police officers make a lot of interventions that give good statistics, but create mistrust. One, out of many examples of manipulating that the Eterno and Silverman (2012) describe in their book entitled "Management by Manipulation", is to change crimes to less serious offences, for example attempted rape is changed to a misdemeanour, like sexual.

Persons who register or take out information in a way that creates a misleading picture of conditions can be seen as some sort of Information Gatekeepers (see Bouhnik \& Giat, 2015). Numbers often conceal quality issues (Alvesson, 2013; see also Bejerot \& Hasselblad, 2011) and unintentional misleading, for example some missing information or differences in quality, can be a prerequisite for successful intentional misleading. Organisations often use illusion tricks to present conditions in a positive light (Alvesson, 2013). An illusion trick involves small changes in the substantial content, where an object is repackaged and presented in a more elegant form (Alvesson, 2013).

Table 1 provides a brief summary of findings from the literature review that can explain how ICT can contribute to misleading pictures of conditions: 
Table 1: Intentional or unintentional factors contributing to answer the research question

\begin{tabular}{|c|c|}
\hline Factor & Research \\
\hline Insufficient system design & $\begin{array}{l}\text { Ash et al., 2004; Davis, 1989; Davis et al., 2006; Grudin, } \\
\text { 1988; Kushniruk et al., 2005; Nicolau \& McKnigth, } 2011\end{array}$ \\
\hline Problem with information quality & $\begin{array}{l}\text { Alvesson, 2013; Bejerot \& Hasselblad, 2011; DeLone \& } \\
\text { McLean, 1992; Eterno \& Silverman, 2012; Lapsley, 2009; } \\
\text { Nicolau \& McKnigth, 2011; Speklé \& Verbeeten, 2014; }\end{array}$ \\
\hline $\begin{array}{l}\text { Accurate information important to be able } \\
\text { to make appropriate judgements }\end{array}$ & Ashrafi et al., 2014; Popovič \& Habjan, 2012. \\
\hline $\begin{array}{l}\text { Different preknowledge, perspectives, etc. } \\
\text { affect the way of interpreting information }\end{array}$ & Hassel, 2005; Hislop, 2002; Walsham, 2004 \\
\hline A socio-technical gap & Ackerman, 2000 \\
\hline $\begin{array}{l}\text { ICT has a key role in persuasion, infor- } \\
\text { mation exchange, and documentation }\end{array}$ & $\begin{array}{l}\text { Ash et al., 2004; Eterno \& Silverman, 2012; Novac-Ududec, } \\
\text { 2015; Stephens et al., } 2008\end{array}$ \\
\hline Information Gatekeepers & Bouhnik \& Giat, 2015 \\
\hline $\begin{array}{l}\text { Too much faith in information presented } \\
\text { by ICT compared to other information } \\
\text { sources }\end{array}$ & Ash et al., 2004; Leveson \& Turner, 1993 \\
\hline Numbers often concealed quality issues & Alvesson, 2013; Bejerot \& Hasselblad, 2011 \\
\hline Dysfunctional behaviours & $\begin{array}{l}\text { Bejerot \& Hasselblad, 2011; Eterno \& Silverman, 2012; } \\
\text { Lapsley, 2009; Speklé \& Verbeeten, } 2014\end{array}$ \\
\hline Manipulations/illusion tricks & Alvesson, 2013; Eterno \& Silverman, 2012; Young 1991 \\
\hline Legitimacy-building & Alvesson, 2013; DiMaggio, 1983; Meyer \& Rowan, 1977 \\
\hline $\begin{array}{l}\text { Use of social media in impression- } \\
\text { management strategies }\end{array}$ & Jackson \& Lilleker, 2011; Shin et al., 2015 \\
\hline $\begin{array}{l}\text { Use of new technologies to create an inno- } \\
\text { vative image }\end{array}$ & Melin et al, 2014. \\
\hline
\end{tabular}

\section{Methodology}

To answer the research question of how the use of ICT can contribute to giving a misleading picture of conditions it has been decided to study cases within one organisation. The word "Conditions" in this context has a wide meaning and includes, for example, the seriousness of a threat, financial situations, the result of organisational change, individuals' work performance, as well as how an operation area works. The purpose of the study is to highlight and clarify the risk that information presented by ICT can be misleading, even if the information gives the impression of being accurate and reliable. For me it was clear that it was necessary to conduct in depth casestudy to understand this complex issue. There has been criticism of case studies, above all about the generalisability, but case studies often create a value for research by an in-depth research method that can generate interesting results (see e.g., Flyvbjerg, 2006; Myer, 2009). It can also be beneficial to make use of other research to answer the research question, i.e., using theory in combination with categorisation of empirical findings in a reflexive research approach (Alvesson \& Sköldberg, 2010; Bryman \& Bell, 2007). 
To answer the research question it was important to be able to go behind the statistics generated by ICT and to detect various patterns. Gaining access to a wide range of different information was therefore essential. In order to make sense of the huge amount of empirical data, Grounded Theory (GT) (see Strauss \& Corbin, 19990) was the research method initially used, as it has advantages in finding categories that can be used in further analyses. The author has conducted over 10,000 hours of participant observations in different areas of operation in the Swedish Police. Participant observations have been carried out at over 100 police stations, where the author took part in police officers' activities in the field, such as traffic surveillance, work against organised crime, narcotics, public order, and school-police activities. Furthermore, more than 2,000 employees in the Swedish Police have been interviewed, mostly in the form of field interviews connected to participant observations, but also with managers and analysts using information from ICT. A wide range of document- and registry studies have also been done. The field interviews were about the police officers' work and possible improvements. Interviews with managers and analysts were about their conclusions and the decisions they make. The purpose of the information collection was to study how the police work in different operational areas and how the work could be improved. Through these studies the author gained an insight, not only into the activities in the field, but also into how different types of information were registered using ICT and how this information was presented, interpreted, and used. Even though it was not the purpose of the studies the author noticed that the work was often presented in a misleadingly positive way (see for example Holgersson, 2007, 2014b, 2015; Woxblom, Holgersson, \& Dolmén, 2008), and the author found that there are good opportunities to use ICT for impression-management, which can be described as a process containing four steps.

The construction of the four-steps process model is based on conclusions from the empirical material that manipulations/illusion tricks were done in a different part of what could be seen as an information chain. First, there was manipulation in the operation field, when data was generated and/or collected. Then, there were manipulations done when data was registered. After that, different types of illusion tricks connected to output of information with ICT were observed, i.e., that statistic print-outs were done in a way that indicated positive results. The fourth step is how output from ICT and ICT itself is used to produce presentations which create a good impression (Holgersson, 2015).

It might be possible to use the just-described four-step process as a framework to help answer the research question for the present study. An analysis with a holistic approach, where it was attempted to place all the separate findings of the literature review into the process model's different steps, resulted however in the conclusion that it was necessary to include one additional step in the model, namely, how information generated by ICT is interpreted. This research study will use empirical data from earlier presented research papers and research reports done within the Swedish Police (see for example Holgersson, 2005, 2007, 2013, 2014a) to see if such a five-step process model (shown in Figure 1) is suitable for answering the research question.

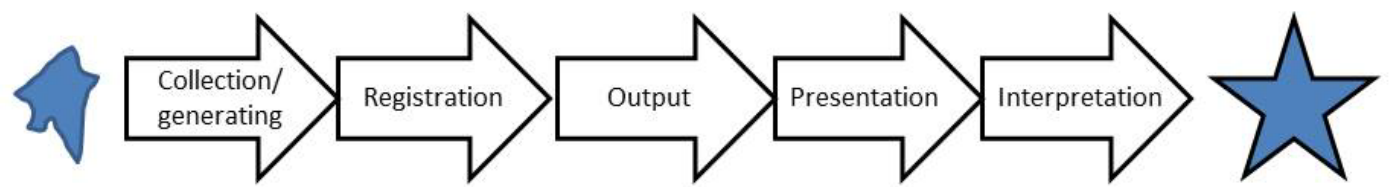

Real condition

Percieved condition

Figure 1: A five-step process model that illustrates how the use of ICT might contribute to a misleading picture of conditions 
Table 2: Methods that were used to gather data for the analysis of the process model

\begin{tabular}{|c|c|}
\hline Step in the process model & Method to gather data \\
\hline Collection/generating & $\begin{array}{l}\text { Participant observations to follow police work in the field } \\
\text { and take part in the way of working, tacit knowledge, dis- } \\
\text { cussions, etc. } \\
\text { Interviews with police officers about issues connected to } \\
\text { this phase; such as dysfunctional behaviours, manipula- } \\
\text { tions, information that not is distributed further, the extent } \\
\text { of a problem, descriptions of situations and phenomena. } \\
\text { - Studies of paper documents to possibly catch information } \\
\text { that was not registered with ICT. } \\
\text { Interviews with, for example, drug addicts, security guards, } \\
\text { social authorities, communication and transportation au- } \\
\text { thorities, and other stakeholders that have contact with the } \\
\text { police or could describe a situation. }\end{array}$ \\
\hline Registration & $\begin{array}{l}\text { Participant observation to observe the registration of infor- } \\
\text { mation and to see and examine the design of ICT solutions. } \\
\text { Register studies to see which information was registered } \\
\text { and to be able to compare this information about a condi- } \\
\text { tion with information from other sources. }\end{array}$ \\
\hline Output & $\begin{array}{l}\text { Participant observation to see which information was used } \\
\text { in different situations. } \\
\text { - Interviews with analysts, managers, etc. about which in- } \\
\text { formation they use for analysis and decision-making, etc. } \\
\text { - Studies of documents and reports to see which information } \\
\text { was used by researchers, analysts, managers, etc. }\end{array}$ \\
\hline Presentation & $\begin{array}{l}\text { - Participant observation to take part in presentations. } \\
\text { - Studies of documents, reports, press releases, websites, } \\
\text { statements by the police in media, etc. } \\
\text { Interviews with managers, police officers, personnel at } \\
\text { communications units, etc. about how information is pre- } \\
\text { sented and possible differences between how information is } \\
\text { presented compared to how things really are. }\end{array}$ \\
\hline Interpretation & $\begin{array}{l}\text { - Interviews with managers, politicians, etc. to obtain } \\
\text { knowledge about how they had interpreted different presen- } \\
\text { tations } \\
\text { - Studies of documents, reports, etc. to see how presentations } \\
\text { have been interpreted } \\
\text { - Observations in media of how presentations have been in- } \\
\text { terpreted }\end{array}$ \\
\hline
\end{tabular}

The study is not about collecting new empirical data but structuring and analysing already collected empirical material. When doing the initially analysis using GT factors that were present in several examples were written down and the goal was then to minimise the number of categories, without making them too generic. The result was six categories where two of the categories included sub-categories. The main goal is then to adopt a holistic approach and see if the five-step 
model could be used as a framework to explain the research question through both using findings from the literature review and from the empirical material. Data from the empirical material that was used to analyse each step in the process-model is presented in Table 2.

Highlighting examples from various fields of activity was assessed to contribute to the credibility of the study, as it indicates that the described phenomenon was not limited to only one area of operation. The large repository of empirical material makes it necessary, however, to make delimitations of examples presented in the empirical section of this paper, such as interview quotes and $\log$ extracts. During international service in the United Nations and the European Union it has been obvious that phenomena described in this study are not unique to the Swedish Police. People working in a wide range of different organisations in Sweden have also spontaneously made contact and described that the observed behaviour in the Swedish Police clearly exists in their organisations. These communications and the fact that the study uses findings from a literature review in the analysis is positive for the validity that the observed phenomena are relevant in a wider context than just the police organisation in Sweden.

\section{Categorisation of Empirical Data Taken from the Swedish Police}

In Sweden there is only one police organisation. The Swedish Police have approximately 20,000 police officers and 8,000 other employees. The organisation is divided into seven regions and nine national departments. Empirical data is collected from all regions.

\section{Defective Data Quality Because Information in ICT Systems is Wrong/Incomplete/Difficult to Interpret}

The empirical data (see for example, Holgersson, 2001, 2005, 2014c) indicates that there is often defective data quality in the ICT systems because information is missing, wrong, incomplete, and difficult to interpret. Factors that seem to influence this condition are:

- The design of ICT solutions

- Lack of motivation by the personnel to register information in a correct/adequate way

- Some knowledge is difficult to formulate using ICT

- Changes in working processes

- Creative accounting and other forms of doping results

\section{The design of ICT solutions}

The police officers usually have to register the same information in different ICT solutions with diverse and often complicated user interfaces. This makes it easy to forget or to make mistakes (Holgersson, 2001, 2005). Improperly designed ICT solutions lead to a lack of information and to the fact that registered information has a low quality (Holgersson, 2001, 2005, 2014c). The problem is not only connected to the design of computer programs, but also to hardware solutions. In a costly project that ended in a shambles after six years, uniformed police officers were supposed to use laptops in the field. Within the context of their work it was particularly not suitable to bring a laptop. Police officers could not expect people to stop fighting or struggling just because they were told that the officers' computer was in danger of being damaged (Holgersson, 2014c).

\section{Lack of motivation by the personnel to register information in a correct/ adequate way}

Cumbersome administrative processes or bad experience of an ICT solution could mean that police officers skipped registering some information at all or intentionally registered information in 
an incorrect or inadequate way. In one police department there was less than ten percent of the documentation there should have been, relating to some types of actions taken by police officers (Holgersson, 2005). Rather than try to input information of as high a quality as possible, users might instead just try to find an easy way to register information. This was the case with the timereporting system. The reality that the statistics would describe was more complex than the concepts and method of accounting. The police officers would, for example, use a different code depending on whether they worked with youth, habitual offenders, or others. If police personnel focused on burglaries in cars in one area, the focus was towards all categories at the same time, and moreover a person could both be a young person and a habitual offender. Furthermore, personnel did not see any benefit with the time-reporting system. The activity was therefore not prioritised and was usually carried out at the end of the week. This made it hard to remember how the hours were allocated to different activities. This, in combination with the difficulty of encoding the registration in the time-reporting system, was something that resulted in most personnel just ticking the boxes and putting in no effort to try and complete the data as fairly as possible (Holgersson, 2001).

\section{Some knowledge is difficult to formulate using ICT}

Much of the police officers' knowledge can be classified as so-called tacit knowledge, i.e., knowledge that is difficult to articulate. Tacit knowledge refers to the know-how gained through experience and practice (Basselier, Reich, \& Benbasat, 2001). Conclusions may be drawn from a person's body language, the tone of voice, or a feeling that something will happen depending on a certain atmosphere (see Holgersson, 2006; Holgersson, Gottschalk, \& Dean, 2008). Direct access to knowledge about a special incident will increase the chances that a person will have a deeper insight into the particular matter compared to interpreting a description of that incident through ICT. The seriousness of a threat can, for example, be difficult to estimate without knowledge about the actual situation (Holgersson, 2001). A threat can be overestimated without direct access. This can lead to the police in the situation acting in too rough a way, which can cause an increasing spiral of violence with huge material and human damage (Holgersson, 2010). In the same way a threat can be underestimated. A police officer who had actually visited a woman threatened within a relationship had a completely different prerequisite to give an accurate picture of the situation to a prosecutor than an investigator who had only read the information from the first-responding patrol, as registered with ICT (see Holgersson, 2005).

\section{Changes in working processes}

Changes in administrative routines, quantitative and qualitative changes in police work, and changes in the law can make it problematic to compare information between different periods and organisations (Holgersson, 2001). For example, when the routines for making a report for a specific crime in a police district were changed, the police officers avoided detecting and reporting that type of crime because their feeling was that the routines were too cumbersome. When the old routines were restored they began to report that specific crime again (Holgersson, 2005). Another example is when a new ICT system was introduced and police officers avoided taking initiatives to detect the type of crimes that required registration in that ICT system (Holgersson, 2014c).

The police organisation has more or less been continually under reconstruction for a long time, and it's the same with a lot of the routines in the organisation (Holgersson, 2014b). These circumstances in combination with new laws, directives, and priorities heighten the risks for misleading information when using ICT, when these changes are not visible. Changes in work processes may also be part of impression-management strategies designed to get appealing results, such as bringing in well-known drug users instead of putting energy into discovering a new user in the riskzone for addiction. In one area ten people were suspected of 150 narcotics crimes during one 
year. One of these people was brought to the police station five times during one week (Holgersson, 2007; Holgersson \& Knutsson, 2011).

\section{Creative accounting and other forms of doping results}

One way of creative accounting was to divide a crime into more than one report, for example one text (SMS) message that was sent to 150 people becomes, instead of one notification, 150 separate reports of attempted drug offences. Harassment made by a man against a woman via SMS was registered as 139 separate crimes (Holgersson, 2014c); when, for example, 32 marijuana plants were found in the forest by a member of the public, the police registered 32 separate narcotics crimes - one for each plant; and when a small plastic bag with narcotics was found on a pavement by a member of the public, five separate narcotics sales were registered (Holgersson, 2011). The way of registering information in the time report system is another example of creative accounting. Demand from above that there must be more foot patrols resulted in more foot patrols being registered in the time-reporting system, but in reality nothing was changed. They likely worked just as before, but the managers were satisfied with the better figures (Holgersson, 2001).

\section{Information Generated by ICT has a Dominant Role when the Result of Work is Evaluated}

There was an awareness among managers that the output from the ICT systems had deficiencies, but they expressed that this was "the best information we have" so, in practice, managers attached great importance to output generated by ICT (Holgersson, 2001). There are four main reasons why information generated by ICT has a dominant role when the result of work carried out is evaluated:

- It is easy to compare results using figures generated by ICT

- Output from an ICT system gives the impression of being accurate and reliable

- Analysts and researchers often use output from the ICT systems as an essential basis for their conclusions

- Lack of a good communication climate

\section{It is easy to compare results using figures generated by ICT}

Norms for what is good policing are often formulated by economists in the police, and output generated by ICT corresponds to a basic attitude of how police work should be managed. It is easy to compare results using figures generated by ICT (Holgersson, 2005; Holgersson \& Knutsson, 2011). To put a qualitative aspect into the evaluation would have been more resourcedemanding and would have required a completely different approach and knowledge about police methods. There is a lack of such knowledge within the police organisation (Holgersson, 2008, 2014a) and the choice of using key-figures generated by ICT is therefore logical (Holgersson, 2014b).

\section{Output from the IT system gives the impression of being accurate and reliable}

Outputs from the IT system, often in the form of colourful, attractive, graphical presentations, easily give the impression of being accurate and reliable (Holgersson, 2001, 2005, 2014b). This information provides a credible impression, facilitates opportunities to build up a particular image and reduces the need to search for alternative information that may be more nuanced and difficult to interpret (Holgersson, 2014b, 2014c). 


\section{Analysts and researchers often use output from the ICT systems as an essential basis for conclusions}

It was common that statements/reports from researchers/analysts were built on output generated by ICT. Statements and reports from researchers and analysts were, however, nearly always seen as a separate information source in relation to output generated by ICT (Holgersson, 2001). If both output generated by ICT and the findings made by researchers and analysts using ICT pointed in the same direction, which of course was natural when they were built on the same source, the result had a strong position compared to other information sources (Holgersson, 2001). There was little need to search for alternative information when there was "such strong proof" that output generated by ICT was sufficient to base a decision upon. Thus, any potential objections to, and points of view about, ICT outputs by members of staff ran the risk of being easily disregarded and seen merely as moaning and complaining (Holgersson, 2001, 2005).

\section{Lack of a good communication climate}

Personnel tended to avoid presenting negative messages, and the more levels of hierarchy the information had to pass through, the more the information seemed to be arranged to suit. The dialogue between different hierarchical levels was defective. Even if someone at a high hierarchical level took the initiative to actually ask for accurate information, there was a risk that he or she was given the information the personnel at a lower hierarchical level supposed that the person who asked wanted to hear (Holgersson, 2014b). Another observed problem was that when, for once, a high-ranking officer went down to listen to officers on the front line, there was so much frustration over different things that the dialogue was not constructive. Apart from the fact that the high-ranking officer's willingness to try to initiate such a dialogue again might be low, there was a risk that even legitimate arguments that output generated by ICT gave a misleading picture of conditions were judged as complaints without any foundation (Holgersson, 2005). A lack of a good communication climate also caused negative effects in the other direction, for example that personnel did not understand why it was important to register some information and, therefore, registered information with ICT that resulted in a low quality of that information or put an effort into quantity aspects rather than quality aspects when carrying out police work. That ICT has a dominant role for evaluation and decision-making became, in a sense, a factor that restricted the achievement of a good communication climate. It was the figures generated by ICT that were in focus and not, for example, the operation's basic goal of reducing traffic injuries (Holgersson, 2014a ; Woxblom et al., 2008).

Personnel at a low hierarchical level registered the information using ICT and had another previous knowledge compared to management trying to interpret output generated by ICT, but they are rarely used to support the interpretation of that output (Holgersson, 2001, 2005). In one police district there was, for example, a question about the effectiveness of using administration personnel. An analyst made a conclusion, from output generated by ICT, that the number of administrators had no effect on the number of cases distributed to the prosecutors. This was used as a basis for a decision to decrease the number of administrators. A police officer explained in an interview that the output from ICT gave an inaccurate picture, but nobody had asked anyone at his level about the effect of fewer administrators at his police station. He meant that the output generated by ICT did not show that police officers have to do more in each case compared to when there were more administrators. That he and other police officers could not be out on the street as much as before, because they had a lot of administration to do, and that they therefore also spent less time on other important activities, such as victim support, was not visible in the output generated by ICT (Holgersson, 2001). 


\section{The Use of ICT Anonymises the Reality behind the Information}

The murder of Prime Minister Palme in Sweden is solved in the statistics, even if it not is solved in the court system. That's because judgements in district courts are the ones that are counted in the statistics (Holgersson, 2001). Information from ICT is often presented on an aggregate level, which means that unique single cases are generalised into the same compartment. A serious threat will, for example, have the same substance as a reported threat in a custody battle which was only to smear the other party. Circumstances behind comprehensive changes in the statistics - such as difficulties for the public to make reports due to a police station having shorter opening times, or a highly active police officer leaving or joining a police station - will not be detectable (Holgersson, 2001, 2005). The use of ICT makes it easy to make different types of compilations, but anonymises the reality behind the information because that quality difference is not visible.

\section{Propaganda}

The police have employed more communicators and information strategists working to bring about positive images of the police, quite often they have a background as journalists. Many times the information was taken from the ICT systems, and ICT itself was important, e.g., through the use of social media, in setting out a good picture of how the operation works. The dissemination of information was often very similar to how a commercial company acts to promote itself. It could be about building up a picture of how the police dealt with a certain problem by highlighting a crackdown. To do so the police, for example, reported how many weapons had been confiscated by using output from ICT. That the method had little or no ability to make an impact was not communicated. Furthermore, the way the police acted could even be counterproductive, but this was nothing that appeared in the presented picture. The police were often both a supplier and interpreter of output generated by ICT. If reported crime decreased it was possible for the police to argue that this was caused by the efforts of the police to reduce crime. If crime on the other hand went up, the police might instead claim that the police worked hard to increase the willingness to report crimes and that the figures were a proof of success. Confidentiality meant that persons outside the police had difficulty to control output generated by ICT. It opened up good opportunities to avoid leaving an accurate image of conditions. Twenty-one different propaganda approaches have been observed, where ICT plays an important role in 10 of them (Holgersson, 2014b).

\section{Different Previous Knowledge, Perspectives and Goals}

Two totally different perspectives have been observed within the Swedish Police, with different previous knowledge, perspectives, and goals (Ekman 1999; Holgersson, 2005). Direct access to knowledge about a special incident will increase the chances that a person will have a deeper insight into the particular matter compared to interpreting a description of that incident through ICT. Different previous knowledge, perspectives, and goals are essential prerequisites for the ability to interpret output generated by ICT in an accurate way (Holgersson, 2001).

\section{Analysis}

In Table 3 findings from the literature review are processed with a holistic approach, in that single explanations of the phenomenon that ICT contributes to misleading pictures of conditions are placed in the five-step process model. For example, insufficient system design is connected to the registration phase, i.e. that users made mistakes so that information might be misleading, and to the output phase because it can be difficult to make some types of compilations. 
Table 3: Single explanations from the literature review placed in the five-step process

\begin{tabular}{|c|c|c|c|c|c|}
\hline Factor & $\begin{array}{l}\text { Collection/ } \\
\text { Generating }\end{array}$ & $\begin{array}{l}\text { Regis- } \\
\text { tration }\end{array}$ & Output & $\begin{array}{l}\text { Presen- } \\
\text { tation }\end{array}$ & $\begin{array}{l}\text { Interpre- } \\
\text { tation }\end{array}$ \\
\hline Insufficient system design & & $\mathrm{x}$ & $\mathrm{X}$ & & \\
\hline Problem with information quality & & & $\mathrm{X}$ & $\mathrm{X}$ & $\mathrm{X}$ \\
\hline $\begin{array}{l}\text { Accurate information important to be } \\
\text { able to make appropriate judgements }\end{array}$ & & & & & $\mathrm{x}$ \\
\hline $\begin{array}{l}\text { Different preknowledge, perspectives, } \\
\text { etc. affect the way of interpreting } \\
\text { information }\end{array}$ & & & & & $\mathrm{X}$ \\
\hline A socio-technical gap & & $\mathrm{x}$ & & & $\mathrm{x}$ \\
\hline $\begin{array}{l}\text { ICT has a key role in persuasion, in- } \\
\text { formation exchange and documenta- } \\
\text { tion }\end{array}$ & & $\mathrm{x}$ & $\mathrm{X}$ & $\mathrm{X}$ & $\mathrm{x}$ \\
\hline Information Gatekeepers & & $\mathrm{x}$ & $\mathrm{X}$ & & \\
\hline $\begin{array}{l}\text { Too much faith in information pre- } \\
\text { sented by ICT compared to other in- } \\
\text { formation sources }\end{array}$ & & & & $\mathrm{x}$ & $\mathrm{x}$ \\
\hline $\begin{array}{l}\text { Numbers often concealed quality } \\
\text { issues }\end{array}$ & & & $\mathrm{X}$ & $\mathrm{x}$ & $\mathrm{x}$ \\
\hline Dysfunctional behaviours & $\mathrm{x}$ & & & & \\
\hline Manipulations/ illusion tricks & $\mathrm{x}$ & $\mathrm{X}$ & $\mathrm{X}$ & $\mathrm{X}$ & \\
\hline Legitimacy-building & $\mathrm{x}$ & & & $\mathrm{X}$ & \\
\hline $\begin{array}{l}\text { Use of social media in impression- } \\
\text { management strategies }\end{array}$ & & & & $\mathrm{X}$ & $\mathrm{x}$ \\
\hline $\begin{array}{l}\text { Use of new technologies to create an } \\
\text { innovative image }\end{array}$ & & & & $\mathrm{X}$ & $\mathrm{x}$ \\
\hline
\end{tabular}

Table 4 shows a summary of how many factors from the literature review that was possible to put into respectively steps in the model.

Table 4: Number of factors from the literature review that were possible to put into each respective step of the process model.

\begin{tabular}{|l|c|c|c|c|c|}
\hline & $\begin{array}{c}\text { Collection/ } \\
\text { Generating }\end{array}$ & Registration & Output & Presentation & Interpretation \\
\hline Number of factors & 3 & 5 & 6 & 8 & 9 \\
\hline
\end{tabular}

According to Table 4, most factors in the literature review were connected to interpretation and the least number of factors to the collection/generation step. It was possible to put findings from the literature review in all steps and all factors from the literature review fit the framework of the process model. The next phase in the study was to do the same thing with the findings from the empirical material. Table 5 is a compilation of how the selected headings in the empirical section match the five-step process model. One more category had been abstracted from the empirical material: "Direct vs. indirect access to a specific case/situation". Even if this category did not 
have its own heading in the empirical presentation the difference between direct vs. indirect access to a specific case/situation was processed under several headings and is defined as an important factor in how the use of ICT can contribute to giving a misleading picture of conditions.

Table 5: A compilation of how the selected headings in the empirical section match the five-step process model described earlier in the paper

\begin{tabular}{|c|c|c|c|c|c|}
\hline Factor & $\begin{array}{l}\text { Collection/ } \\
\text { Generating }\end{array}$ & $\begin{array}{l}\text { Regis- } \\
\text { tration }\end{array}$ & Output & $\begin{array}{l}\text { Presen- } \\
\text { tation }\end{array}$ & $\begin{array}{c}\text { Inter- } \\
\text { preta- } \\
\text { tion }\end{array}$ \\
\hline $\begin{array}{l}\text { Defective data quality because information } \\
\text { in ICT systems is wrong/incomplete/ diffi- } \\
\text { cult to interpret }\end{array}$ & $\mathrm{x}$ & $\mathrm{x}$ & $\mathrm{x}$ & $\mathrm{x}$ & $\mathrm{x}$ \\
\hline Design of ICT solutions & $\mathrm{x}$ & $\mathrm{x}$ & $\mathrm{x}$ & & \\
\hline $\begin{array}{l}\text { Lack of motivation by the personnel to regis- } \\
\text { ter information in a correct/adequate way }\end{array}$ & & $\mathrm{x}$ & & & \\
\hline $\begin{array}{l}\text { Some knowledge is difficult to formulate } \\
\text { using ICT }\end{array}$ & & $\mathrm{x}$ & & & \\
\hline Changes in work processes & $\mathrm{x}$ & $\mathrm{x}$ & & & \\
\hline $\begin{array}{l}\text { Creative accounting and other forms of dop- } \\
\text { ing results }\end{array}$ & & $\mathrm{x}$ & & & \\
\hline $\begin{array}{l}\text { Information generated by ICT has a domi- } \\
\text { nant role when the result of work is evalu- } \\
\text { ated }\end{array}$ & & & $\mathrm{x}$ & $\mathrm{x}$ & $\mathrm{x}$ \\
\hline $\begin{array}{l}\text { It is easy to compare results using figures } \\
\text { generated by ICT }\end{array}$ & & & $\mathrm{x}$ & $\mathrm{x}$ & $\mathrm{x}$ \\
\hline $\begin{array}{l}\text { Output generated by ICT gives the impression } \\
\text { of being accurate and reliable }\end{array}$ & & & $\mathrm{x}$ & $\mathrm{x}$ & $\mathrm{x}$ \\
\hline $\begin{array}{l}\text { Analysts and researchers often use output } \\
\text { from ICT systems as an essential basis for } \\
\text { conclusions. }\end{array}$ & & & $\mathrm{x}$ & $\mathrm{x}$ & $\mathrm{x}$ \\
\hline Lack of a good communication climate & & & & & $\mathrm{x}$ \\
\hline $\begin{array}{l}\text { The use of ICT anonymises the reality be- } \\
\text { hind the information }\end{array}$ & & & & & $\mathrm{x}$ \\
\hline Propaganda & & & $\mathrm{x}$ & $\mathrm{x}$ & \\
\hline $\begin{array}{l}\text { Different previous knowledge, perspectives } \\
\text { and goals }\end{array}$ & & & & & $\mathrm{x}$ \\
\hline $\begin{array}{l}\text { Direct vs. indirect access to a specific } \\
\text { case/situation }\end{array}$ & & & & & $\mathrm{x}$ \\
\hline
\end{tabular}

In Table 6 there shows a summary of how many factors from the empirical material that was possible to put into respectively steps in the model. 
Table 6. Number of factors from the literature review that were possible to put into each respective step of the process model

\begin{tabular}{|l|c|c|c|c|c|}
\hline & $\begin{array}{c}\text { Collection/ } \\
\text { Generating }\end{array}$ & Registration & Output & Presentation & Interpretation \\
\hline Number of factors & 3 & 6 & 7 & 6 & 9 \\
\hline
\end{tabular}

There were in general a lot of similarities between the findings from the literature review and the empirical material, even if there were some differences. An extended literature review was done to see if it was possible to find more explanations from previous research studies connected to findings in the empirical material.

\section{Collecting/Generating}

A willingness to be able to show pleasant images may lead to the fact that police personnel take shortcuts to affect the statistics rather than applying methods that may give the desired effects. For example, in the work in the area of road safety and narcotics crimes it was possible to observe instances of such behaviour (Holgersson, 2007, 2014b). Researchers have identified such behaviour in other organisations (Eterno \& Silverman, 2012; Young, 1991). The empirical data showed that goal displacement was common in the Swedish Police (see for example, Holgersson \& Knutsson, 2011, 2012a) and this is definitely not a unique phenomenon in organisations (see for example, Bejerot \& Hasselbladh, 2011; Merton, 1968; Perrin, 1998). There are a great number of examples from the public sector indicating that focusing on quantitative data generated by ICT can cause dysfunctional behaviours in organisations (see for example, Kelman \& Friedman, 2009; Lapsley, 2009; Speklé \& Verbeeten, 2014). An example from the Swedish Police was the focus on the number of breathalyser tests registered with ICT. Where and when the tests were done was not of interest. An effect of that was that most tests were carried out when the risk for drunken driving was the lowest and vice versa - when the risk was highest for drunken driving, tests were at the lowest level. In some cases police officers received direct orders to stand in places where the risk of finding drunk drivers was low. The explanation was simple. If police officers actually found a drunk driver they would not be able to carry out further breathalyser tests during the time it took to record the detected crime, necessary for the driver to be prosecuted. This often included transportation of the drunk driver to a police station. The focus on key figures retrieved from ICT was counterproductive for the police work in the road safety area (Holgersson, 2014a, 2014b; Woxblom et al., 2008).

The conditions highlighted so far in this category involve primarily an aim to be able to give a good impression by showing an appealing picture of the operation. Actions that end up under this category, however, also concern other forms of behaviour that affect the quality of the information used as a basis for making comparisons using ICT. This may involve changes in the work processes, due to reorganisations, the use of new technologies, or new legislative support. Cumbersome IT systems could lead to personnel avoiding carrying out certain actions which could make a particular type of crime appear to be reduced (Holgersson, 2001). Research has also shown that job performance differs greatly between different police officers. Some police officers are extremely highly productive, while others do not do things on their own initiative. These conditions have a great effect on the statistics (Holgersson \& Knutsson, 2012b).

\section{Registration}

For example, the research field of Human-Computer Interaction (HCI) provides a number of explanations of what role ICT can play in giving a misleading picture of conditions. It is connected to the design of systems, which is important in how the data exchange interaction works (see 
for example, Davis et al., 2006; Nicolau \& McKnight, 2011). This empirical material shows that insufficient ICT solutions led to mistakes and a lack of motivation by personnel to register information in a correct/adequate way but also led to changes in work processes when registering information. All of this influenced the statistics (Holgersson, 2001, 2014a). Thus, there is good theoretical support for the fact that the design of ICT solutions, with no intention of giving a misleading picture of conditions, can give such an effect. In the same way there is a lot of research that backs up the findings in this study that some knowledge is difficult to formulate using ICT and that this can lead to the fact that information using ICT can be incomplete (see for example, Hislop, 2002).

In the study it has also been observed that there is an intention to show good results when registering information using ICT. This was, for example, the case in investigation activities (Holgersson, 2014b) and narcotics crimes (Holgersson \& Knutsson, 2011). Other researchers have highlighted this type of manipulation when using ICT (Eterno \& Silverman, 2012). Even if this type of manipulation has been observed in other organisations there is limited research into what kind of role ICT can play in impression-management strategies. This study shows that there are many opportunities to manipulate the results when registering information with ICT (see also Holgersson, 2015), but as mentioned above there is also a wide range of other factors in the registration phase that can give a misleading picture of conditions.

\section{Output}

From the empirical data from the Swedish Police it is possible to see how the use of ICT can contribute to giving a misleading picture of conditions. Even if output - in the form of colourful, attractive, graphical presentations - easily gives the impression of being accurate and reliable, there is a risk of defective data quality (Holgersson, 2001, 2005, 2014b). Other researchers have also identified this problem (see for example, Eterno \& Silverman, 2012; Luft, \& Hunt, 1986). Information about specific cases was often presented in aggregated form in the way the Swedish Police used ICT, and figures seemed to be valued as more important than the truth behind them (Holgersson, 2001, 2014b). This conclusion has been made by other researchers when they observed organisations (see for example, Bejerot \& Hasselblad, 2011; Brunsson, 1989, 1993; Power, 1997). Lastly, the design of ICT solutions influences the quality of the output (Holgersson, 2001). It is possible to find support for the findings that it is important to take system design into consideration when using output generated by ICT for analysis (see Nicolau \& McKnight, 2011). Thus, the analysis shows that problems with defective data quality when using output generated by ICT are well known in the research literature.

\section{Presentation}

Presentation is listed as a separate step because of the fact that it is about how output generated by ICT is selected to be presented, and about how ICT itself is used to set out a good picture of how the operations work. This step is important in the impression-management strategy (Holgersson, $2014 b)$. Even if there is limited previous research into what role ICT can play in impressionmanagement strategies, it is possible to use findings from other research areas. Over the years many researchers have highlighted this condition, often called legitimacy-building (see e.g., Alvesson, 2013; DiMaggio, 1983; Meyer \& Rowan, 1977). There are good opportunities to use ICT to build up appealing pictures that give an accurate and reliable impression and good options to hide defective data quality because presentation is done on an aggregate level, where individual cases behind the statistics are not visible (Holgersson, 2001, 2014b). Earlier research referred to that figures are seen as more valued and more important than the truth behind them (see for example, Brunsson, 1989, 1993) - is also highly relevant to mention in this step. What role ICT can play in giving a misleading picture of conditions is not only about propaganda. A lack of a good 
communication climate affects which type of output is used in presentations. Output in line with perceptions is overemphasised while information that speaks against them is suppressed (Holgersson, 2014b). The output of ICT contributes in creating misleading images of different conditions; this might not be a part of deliberate propaganda but the effect is the same. The use of ICT makes it possible to extract a wide range of information, but what this information is really saying is another matter (Holgersson, 2001, 2014b). This phenomenon, which it is not about a lack of relevant information, but an abundance of irrelevant information, is an old, well-known problem (see for example, Ackoff, 1967).

\section{Interpretation}

The empirical data shows that it is not unusual to have defective data quality because information using ICT is wrong/incomplete/difficult to interpret. However, output generated by ICT has a dominant role when the result of work is evaluated and direct vs. indirect access to cases/situations influences the possibilities of interpreting output generated by ICT in an accurate way (Holgersson, 2001). There is plenty of research that different previous knowledge, perspectives, and goals affect the way of interpreting information (see for example. Bolman \& Deal, 2003; Lin et al., 2005; Woxblom et al., 2008). A recipient's tendency is to trust information already learned, accepted, and understood. The risk is large that he or she will reject other information. This phenomenon is called selective perception (Dearborn \& Simon, 1958). Organisational researchers have found that many important decisions taken in organisations are affected by managers' personal cognitive processes (see for example, Hambrick \& Mason, 1984). Admittedly these findings have to some extent been revised, where researchers have concluded that it is rather about selective imperceptions, i.e., failure to perceive (Beyer, Chattopadhyay, George, Glick, Ogilvie, \& Pugliese, 1997).

This study also shows that the lack of a good communication climate affects the prerequisite to interpret output generated by ICT in an appropriate way. The phenomenon that information is filtered on its way up in an organisation is also an old and well-known problem (see e.g., Bradley, 1978; Manis, Cornell, \& Moore, 1974; O'Reilly, 1978). This leads to a great risk that decisionmakers at a high level in the organisation are not as well informed as they believe themselves to be (Holgersson, 2014b). That output generated by ICT and statements/reports from researchers or analysts are seen as separate information sources, even if the information often comes from the same source, makes the situation worse. Output generated by ICT can easily be seen as an answer key and a mapping of an "objective reality" (Lyytinen, 1983). It is not surprising, in accordance with the assumption above, that knowledge from personnel at a low hierarchical level in the organisation is rarely used to interpret output generated by ICT. The importance of using knowledge by employees at a low hierarchical level in solving problems in an organisation has been described by other researchers (see e.g., Hackman \& Oldham, 1980).

\section{Conclusion and Discussion}

What role ICT can play in giving a misleading picture of conditions can be described as a process divided into five steps. The first step is about how the data is generated and/or collected. The second step is linked to how the data is registered. The third step is about the output generated from the ICT systems. The fourth step is how the output of ICT is selected to be presented and how ICT itself is used to present how the operations work. The fifth step concerns how output generated by ICT is interpreted.

How an ICT system is designed is one reason that information generated by ICT can be misleading, and a number of research articles address the importance of an appropriate system design (see e.g., Davis et. al., 2006; Nicolau \& McKnight, 2011). Another reason is that the use of ICT can be a part of impression-management strategies. Even if there is limited research about this 
matter, there is a lot of research showing that it is common in organisations to use so called legitimacy-building activities to create a good picture of the operations (see e.g., Alvesson, 2013; DiMaggio, 1983; Meyer \& Rowan, 1977). There are many opportunities to use ICT as a part of an impression-management strategy. The way of interpreting information and how that information is presented on an aggregate level, where the individual cases are hidden, represents an explanation of how ICT can play an important role in giving a misleading picture of conditions. It is possible to use research in management and communication theory, for example, selective perception - or rather selective imperceptions - as one explanation (see e.g., Beyer et. al., 1997; Dearborn \& Simon, 1958; Hambrick \& Mason, 1984).

This paper contributes to the limited research on roles ICT can play in impression-management strategies and also gives a theoretical contribution by adopting a holistic approach to explain how ICT can contribute to giving a misleading picture of conditions. There is also a practical implication. What has been highlighted and explained in this paper can contribute to decision-makers becoming more aware and not focusing too much on output from ICT and, for example, encouraged to use help from personnel at a low hierarchical level to interpret output generated by ICT. For the most part factors from the literature review that could explain how ICT could contribute to misleading pictures of conditions were found in the empirical data. Some of the identified factors in the literature review and the empirical material were the same or nearly the same, such as the explanation of insufficient system design, while others covered a part of a factor or were on a different level of detail. For example the factor in the literature review of "Too much faith in information presented by ICT compared to other information sources" is a wider explanation than the factor found in the empirical material, "Information generated by ICT has a dominant role when the result of work is evaluated", because it is not limited to evaluations alone. On the other hand this factor in the empirical material has four sub-categories that explain the phenomenon in more detail compared to the literature review. The sub-categories are the following: "It is easy to compare results using figures generated by ICT", "Output generated by ICT gives the impression of being accurate and reliable", "Analysts and researchers often use output from ICT systems as an essential basis for conclusions." and "Lack of a good communication climate". A factor in the literature review, "Use of new technologies to create an innovative image", had no counterpart in the emerged categories from the empirical data. There were, however, two examples of this factor in the empirical material, but this did not meet the criteria - that a factor must be present by several examples in the empirical material - to be defined as a category. Without that criteria there would have been more factors generated from the empirical material and this indicates the need for conducting further studies.

The aim of this study was to adopt a holistic approach that can create an understanding of how the use of ICT can contribute to misleading pictures of conditions. The process model that can facilitate making an entirety of single explanations was the main result of the study. In this paper, the examples presented to illustrate how the use of ICT can contribute to misleading pictures of conditions have been taken from different operations within the police in order to clarify the phenomenon and to show that this is not limited to one area of operations. The findings from the literature review supported and complemented the empirical data. Previous research presented in this paper is especially valid for police organisations, but also for other politically controlled organisations. However, the literature review and contacts in other organisations strongly indicated that the phenomena observed in the Swedish Police are common in other types of large organisations. In smaller organisations with a good communications climate it is most likely that the use of ICT does not involve the risk described in this paper. There is a need for further research on other organisations to enhance the understanding of how the use of ICT can contribute to giving misleading pictures of conditions. It would be possible to use the framework presented in this paper in the analysis of other organisations. 
One way of continuing the research within the Swedish Police and other organisations is to concentrate a study on one step in the process model, as a suggestion the collection/generating step to begin with, because it has less exemplified factors that explain the phenomena. Another way of increasing the understanding of the phenomena is to concentrate the study to a single operation and give detailed examples, both quantitative and qualitative, of how a misleading picture of a condition is generated through the five-step process.

The subject of this paper is highly relevant since output from ICT in, for example, follow-up procedures plays a more and more central role. Paradoxically, the large investments made in ICT in organisations in order to help increase performance have, at some point, given rise to the opposite effect and this should, therefore, be an important theme for further studies.

\section{References}

Ackerman, M. (2000). The intellectual challenge of CSCW: The gap between social requirements and technical feasibility. Human-Computer Interaction, 15(2), 181-203.

Ackoff, R. L. (1967). Management misinformation systems. Management Science, 14(4), 147-156.

Alvesson, M. (2013). The triumph of emptiness, consumption, higher education, and work organization. Oxford: Oxford University Press.

Alvesson, M., \& Sköldberg, K. (2010). Reflexive methodology new vistas for qualitative research (2nd ed.). London: SAGE Publications Ltd.

Ash, J., Berg, M., \& Coiera, E. (2004). Some unintended consequences of information technology in health care: The nature of patient care information system-related errors. Journal of the American Medical Informatics Association, 11(2), 104-112.

Ashrafi, N., Kelleher, L., \& Kuilboer, J-P. (2014). The impact of business intelligence on healthcare delivery in the USA. Interdisciplinary Journal of Information, Knowledge, and Management, 9, 117-130. Retrieved from http://www.ijikm.org/Volume9/IJIKMv9p117-130Ashrafi0761.pdf

Bassellier, G., Reich, B., \& Benbasat, I. (2001). Information technology competence of business managers: A definition and research model. Journal of Management Information Systems, 17(4), 159-182.

Bejerot, E., \& Hasselbladh, H. (2011). Professional autonomy and pastoral power: The transformation of quality registers in Swedish health care. Public Administration, 89(4), 1604-1621.

Beyer, J. M., Chattopadhyay, P., George, E., Glick, W. H., Ogilvie, D. T., \& Pugliese, D. (1997). The selective perception of managers revisited. Academy of Management Journal, 40(3), 716-737.

Bolman, L., \& Deal, T. (2003). Artistry, choice and leadership. New York: John Wiley \& Sons.

Bouhnik, D., \& Giat, Y. (2015). Information gatekeepers - Aren"t we all? Informing Science: the International Journal of an Emerging Transdiscipline, 18, 127-144. Retrieved from http://www.inform.nu/Articles/Vol18/ISJv18p127-144Bouhnik1534.pdf

Bradley, A. (1978). How energy affects the economy. Lexington, Mass: Lexington Books.

Brunsson, N. (1989). The organization of hypocrisy: Talk, decision and action in organizations. New York: John Wiley \& Sons.

Brunsson, N. (1993). Ideas and actions. Justification and hypocrisy as an alternative to control. Accounting, Organization and Society, 18(6), 489-506.

Brunsson, N. (2003). Organized hypocrisy. In B. Czarniawski \& G. Sevon (Eds.), Northern lights. Malmö: Liber.

Bryman, A., \& Bell, E. (2007). Business research methods. New York, NY: Oxford University Press.

Davis, F. (1989). Perceived usefulness, perceived ease of use, and user acceptance of information technology. MIS Quarterly, 13(3), 319-340. 
How the use of ICT can contribute to a misleading picture of conditions

Davis, F., Bagozzi, R., \& Warshaw, P. (2006). Extrinsic and intrinsic motivation to use computers in the workplace. Journal of Applied Social Psychology, 22(14), 1111-1132.

DeLone, W. H. \& McLean, E. R. (1992). Information systems success: The quest for the dependent variable. Information Systems Research, 3(1), 60-95.

Dearborn, D. C., \& Simon, H. A. (1958). Selective perception: A note on the departmental identifications of executives. Sociometry, 21, 140-144.

DiMaggio, P. I. (1983). State expansion and organizational fields. In R. H. Hall \& R. E. Ouinn (Eds.). Organizational theory and public policy. Beverly Hills, CA: Sage.

Ekman, G. (1999). Från text till batong - Om poliser, busar och svennar [From text to bat], Doctoral Dissertation. Stockholm: Ekonomiska Forskningsinstitutet, Handelshögskolan.

Eterno, A., \& Silverman, E. (2012). The crime numbers game: Management by manipulation, New York: CRC Press.

Flyvberg, B. (2006). Five misunderstandings about case-study research. Qualitative Inquiry, 12(2), 219245.

Grudin, J. (1988). Why CSCW applications fail: Problems in the design and evaluation of organizational interfaces. CSSW' 88 Proceedings of the 1988 conference on Computer-supported cooperative work, 85-93.

Hackman, J. R., \& Oldham, G. R. (1980). Work redesign. Reading, MA: Addison Wesley.

Hambrick, D. G., \& Mason, P. A. (1984). Upper echelons: The organization as a reflection of its top managers. Academy of Management Review, 9, 193-206.

Hassel, L. (2005). Pragmatics, speech acts, and knowledge management. In Proceedings of the 3rd Intl Conf. on Action in Language. Organizations and Information Systems (ALOIS-2005). Limerick: University of Limerick, 133-147.

Hislop, D. (2002). Mission impossible? Communicating and sharing knowledge via information technology. Journal of information Technology, 17(3), 165-177.

Holgersson, S. (2001). IT-system och filtrering av verksamhetskunskap - kvalitetsproblem vid analyser och beslutsfattande som bygger på uppgifter hämtade från polisens IT-system. [In Swedish. IT-system and filtering of work practice knowledge - The problem of quality in analysis of and decision- making grounded on information from the internal police IT-system] Linköping: Institutionen för datavetenskap, Linköpings universitet.

Holgersson, S. (2005). Yrke: polis - Yrkeskunskap, motivation, IT-system och andra förutsättningar för polisarbete. [In Swedish. Profession: police - Occupational knowledge, motivation, IT-system and other requirements for police work]. Doctoral dissertation. Linköping: Institutionen för datavetenskap, Linköpings universitet.

Holgersson, S. (2006). Police officers professional knowledge. Report 2006-1. Stockholm: Swedish Police Academy.

Holgersson, S. (2007). Kartläggning av svenska polisens narkotikabekämpning, [In Swedish. A mapping of the Swedish Police fight against narcotics] Rapport 23. Stockholm: Mobilisering mot narkotika, Socialdepartementet.

Holgersson, S. (2008). Spelar skillnader i arbetsprestation mellan poliser någon egentlig roll? [In Swedish. Do differences in work performance between police officers really matter?] Rapport 006-2008. Växjö: Växjö universitet.

Holgersson, S. (2010). Dialogue police. Report. Stockholm: Swedish Police National board.

Holgersson, S. (2011). Appendix till rapporten polisens arbete mot narkotika. [In Swedish. Appendix to the report about the Swedish Police fight against narcotics] Linköping: Institutionen för ekonomisk och industriell utveckling, Linköpings universitet. 
Holgersson, S. (2013). Sättet att bygga fasader inom svensk polis. En analys av presenterad bild jämfört med verkligt utfall. [In Swedish. The process of building facades within the Swedish Police - An analysis of the displayed image compared to the real outcome] Nordisk Tidskrift for Kriminalvidenskab, 2013:1, 112-130

Holgersson, S. (2014a). Polisens trafiksäkerhetsarbete. [In Swedish. Police road safety work] Rikspolisstyrelsens utvärderingsfunktion. Rapport 2014:1. Stockholm: Rikspolisstyrelsen.

Holgersson, S. (2014b). Polisen bakom kulisserna. [In Swedish. The Police behind the scenes] Åby: Åby PC-system.

Holgersson, S. (2014c). Underlag till beslut om Pust/Siebel. [In Swedish. Basis for decision on Pust / Siebel] Verksledningskansliet Stockholm: Rikspolisstyrelsen.

Holgersson, S. (2015). How ICT can contribute to the use of impression-management strategies in a public organization. Twenty-first Americas Conference on Information Systems, Puerto Rico, 2015.

Holgersson, S., Gottschalk, P., \& Dean, G. (2008). Operational knowledge of patrolling police officers in Sweden: Management implications. International Journal of Management and Enterprise Development, 5(1), 49-62

Holgersson, S., \& Knutsson, J. (2011). Polisens arbete mot narkotika. [In Swedish: The Police work against narcotics]. Rikspolisstyrelsens utvärderingsfunktion. Rapport 2011:1. Stockholm: Rikspolisstyrelsen.

Holgersson, S., \& Knutsson, J. (2012a). Vad gör egentligen polisen?. [In Swedish. What do the police really do?] Liu-iei-research report-12/0004. Linköping: Linköpings universitet.

Holgersson, S., \& Knutsson, J. (2012b). Differences in performance among Swedish uniformed police officers. Policing: A Journal of Policy and Practice, 6(2), 210-217.

Jackson, N., \& Lilleker, D. (2011). Microblogging, constituency service and impression management: UK MPs and the use of Twitter. The Journal of Legislative Studies, 17(1), 86-105.

Kelman, S. J., \& Friedman, J. N. (2009). Performance improvement and performance dysfunction: An empirical examination of impacts of the emergency room wait-time target in the English National Health Service. Journal of Public Administration Research and Theory, 19(4), 917-946.

Kushniruk, A., Triola, M., Borycki, E., Stein, B., \& Kannry, L. (2005). Technology induced error and usability: The relationship between usability problems and prescription errors when using a handheld application. International Journal of Medical Informatics, 74(7-8), 519-526.

Lapsley, I. (2009). New public management: The cruellest invention of the human spirit? Abacus: Accounting, Finance and Business Studies, 45(1), 1-21.

Leveson, N. G., \& Turner, C. S. (1993). An investigation of the Therac-25 accidents. Computer, 26(7), 1841

Lin, L., Geng, X., \& Whinston, A. (2005). A sender-receiver framework for knowledge transfer. MIS Quarterly, 29(2), 197-219.

Luft, H. S., \& Hunt, S. S. (1986). Evaluating individual hospital quality through outcome statistics. The Journal of the American Medical Association, 255(20), 2780-2784.

Lyytinen, K. (1983). Reality mapping or language development - A tentative analysis of alternative paradigms for information modelling, SYS LAP wp No. 27, Stockholm: Stockholm University.

Manis, M., Cornell, S. D., \& Moore, J. C. (1974). Transmission of attitude-relevant information through a communication chain. Journal of Personality and Social Psychology, 30, 81-94.

Melin, U., Sarkar, P. K., \& Young, L. W. (2014). Fashions in the cloud: A case of institutional legitimacy. Twentieth Americas Conference on Information Systems, Savannah, 2014.

Merton, R. (1968). Social theory and social structure. New York: Free Press. 
How the use of ICT can contribute to a misleading picture of conditions

Meyer, J., \& Rowan, B. (1977). Institutionalized organizations. Formal structure as myth and ceremony. American Journal of Sociology, 83(2), 340-363.

Myer, M. (2009). Qualitative research in business \& management. London: SAGE Publications.

Nicolao, A., \& McKnight, H. (2011). System design features and repeated use of electronic data exchanges. Journal of Management Information Systems, 28(2), 269-304.

Nonaka, I. (1994). A dynamic theory of organizational knowledge creation. Organization Science, 5(1), $14-37$.

Novac-Ududec, C. (2015). The IT impact in management decision making in Romanian companies: A case study. Medicine, 21(1), 5-10.

O'Reilly, C. A. (1978). The intentional distortion of information in organizational communication: A laboratory and field investigation. Human Relations, 31, 173-193.

Perrin, B. (1998). Effective use and misuse of performance measurement. American Journal of Evaluation, 19(3), 367-379.

Polanyi, M. (1962). Personal knowledge - Towards a post-critical philosophy. London:Routledge.

Popovič, A., \& Habjan, A. (2012). Exploring the impact of decision making culture on the information quality - Information use relationship: An empirical investigation of two industries. Issues in Informing Science \& Information Technology, 9, 125-134. Retrieved from http://iisit.org/Vol9/IISITv9p125134Popovic027.pdf

Power, M. (1997). The audit society: Rituals of verification. Oxford: Oxford University Press.

Shin, W., Augustine, P., \& Hyo Jung, K. (2015). Building relationships through integrated online media global organizations' use of brand web sites, Facebook and Twitter. Journal of Business and Technical Communication, 29(2), 184-220.

Speklé, R. F., \& Verbeeten, F. H. M. (2014). The use of performance measurement systems in the public sector: effects on performance. Management Accounting Research, 25(2), 131-146.

Stephens, K., Sørnes, J. O., Rice, R., Browning, L., \& Sætre, A. S. (2008). Discrete, sequential, and followup use of information and communication technology by experienced ICT users. Management Communication Quarterly, 22(2), 197-231.

Strauss, A. L., \& Corbin, J. (1990). Basics of qualitative research. Grounded theory procedures and techniques. Newbury Park: SAGE Publications.

Walsham, G. (2004). Knowledge management systems: Action and representation. In Proceedings of The $2^{\text {nd }}$ International Workshop on Action in Language. Organizations and Information Systems (ALOIS2004). Linköping: Linköpings University.

Woxblom, C., Holgersson, S., \& Dolmén, L. 2008. Polisens sätt att genomföra och redovisa LAU-tester. En explorative studie av polisens trafiksäkerhetsarbete. [In Swedish. The police's way of conducting breathalyzer tests. An explorative study of the police road safety work] Solna: Polishögskolan.

Young, M. (1991). An inside job. Oxford: Oxford University Press. 


\section{Biography}

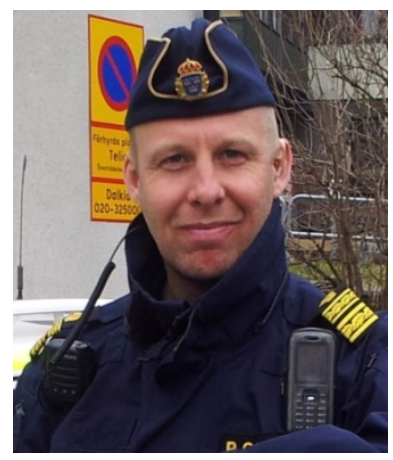

Dr. Stefan Holgersson is an assistant professor at Linköping University. Besides teaching and research he is director of studies in information systems. He also works as a Police Officer in Stockholm and has, on several occasions, acted as a whistleblower in terms of highlighting problems within the Swedish Police. 